Clinica Chimica Acta, 58 (1975) 1-15

(C) Elsevier Scientific Publishing Company, Amsterdam - Printed in The Netherlands

CCA 6355

\title{
HYPERLIPOPROTEINAEMIA IN PONIES: MECHANISMIS AND RESPONSE TO THERAPY
}

\author{
TH. WENSING ${ }^{a}$, C.M. VAN GENT ${ }^{b}$, A.J.H. SCHO'TMAN ${ }^{a}$ and J. KRONEMAN ${ }^{a}$ \\ ${ }^{a}$ Clinic for Large Animal Medicine, State University of Utrecht, Utrecht and ${ }^{b}$ Gaubius \\ Institute, Health Research Organisation TNO, Leiden (The Neliterlands)
}

(Received June 13, 1974)

\section{Summary}

(I) The lipid and lipoprotein concentrations in sera of 4 healthy and 9 hyperlipaemic patients were determined. From the results of the analyses, it is suggested that three types of hyperlipoproteinaemia can be distinguished in ponies:

(a) Type 1 , characterised by a very pronounced increase in only the very low density lipoproteins (VLDL);

(b) Type 2, in which there is a pronounced increase in the chylomicions (Chylo) and the very low density lipoproteins (VLDL);

(c) Type 3, which can be the result of fasting and is characterised by a moderate increase in the concentration of chylomicrons anci a greater increase in very low density lipoproteins.

It is suggested that hyperlipoproteinaemia in ponies $>3: 5 . \cdots$ vissified on the basis of electrophoretic patterns.

(II) To gather more information on the metabolism of extra offered lipids, blood from ponies suffering from two different types of hyperlipoproteinaemia was transfused into normal ponies and the changes in lipid and lipoprotein conceitrations in the blood serum were followed. The reactions were different. Wher heparin was used as anticoagulant a great increase in chylomicrons and a cim: ricant increase in very low density lipoproteins in a healthy pony was observed. When sodium citrate was used as anticoagulant a clear increase in the VLDL fraction only was noticéd.

Abbreviationr: Lipoproteins: LP, lipoproteins; Chylo, chylomicrons; VLDL, very low density lipoproteins $=$ pre- $\beta$-lipoproteins; LDL, low density lipoproteins $=\beta$-lipoproteins; HDL, high density lipoproteins $=\alpha$-lipoproteins.

Lipids: TL, total lipids: tot $\mathcal{C}$, total chclesterol $(=\mathrm{CE} / 1.7+\mathrm{C}) ; \mathrm{PL}$, phospholipids; $\mathrm{C}$, free cholesterol; CE, cholestery lesters: TG, triglycerides; DG, diglycerides; FFA, free fatty acids. 
(III) During treatment with glucose, galactose and insulin of two ponies affected with the same iype of hyperlipoproteinaemia it was found that the lipc protein and lipid concentrations in the blood of both ponies changed in a corresponding way and became normal. Both ponies subsequently recovered.

\section{Introduction}

In a previous studiy, Schotman and Wagenaar [1] described disturbances in fat metabolism in ponies and found normal lipid and enzyme values in the blood serum of clinically healthy ponies. Furthermore, they concluded that hyperlipoproteinaemia in penies is in.ciated by a failure of ponies to eat which results in the sivi:ization of endogenous fat. This leads to more than a 50-fold increase in blood serum triglyceride (TG) values and to a faity liver. Hyparlipaemia in ponies is a disorder with a very poor prognosis; about $65 \%$ of the patients die [2-6]. By means of paper electrophoresis Schotman [5] found that there was an enormous increase in total $\beta$-lipoprotein $(\beta-L P)$ concentration in the ijood of hyperlipaemic ponies (at that time a separation between $\beta$ - and pre-i 3 - L could not yet be achieved).

Bartley [7] noted in 1970 that the lipoprotein that was increased in hyperipaemia was VLDL, (pre- $\beta$-LP).

The investigations described in this paper were aimed at providing further data on changes in the lipoprotein spectrum in ponies suffering from hyperlipobrote acmia. Because of differences in response to therapy we expected different types of hyperlipoproteinaemia as was found by Frederickson and Lees [8] in comection with human hyperlipoproteinaemia. Morris et al. [9] described changes in blood serum lipoprotein pattems in ponies with only a very mild forn of hypeilipoproteinatinia induced by fasting. However, lipoproteins were isolated by ultracentrifugation in such a manner that criylomicrons and VLDL were not separated. Upon analysis of the lipids from the LP fractions, they noted remarkably low cholesterylesters to total cholesterol (CE; lotal $C$ ) ratios. in our study, chylomicrons, VLDL, I, Th and HDL were isolated as separate Thations by preparative ultracentrifugation technique as well as by very good rorrelating paper electrophoretic senarations.

Because hyperlipoproteinaemia in ponies also develops during fasting [16], Schotman [5] suggested that hyperlipoproteinaemia was the result of an increased mobilisation of lipids. An enormous offer of mobilised lipids strould catise the observed shifts in the lipoprotem spectrd of lipaemic pon:-

'To gather additional information on the metabolism of extra oletec! lipids in our stuly, lipaemic: hood from two sick ponies was transfused into two healthy ponies. As is known heparin activates the lipoprotein lipase $\{5,10\}$ Therefore in the blood coming from patient 1 , heparin was used as anticoagulant. In the blond of the other pony sodium citrate was used as anticoagulant.

Finally, we gathered some data during a treatment with glucose, galactose and insulin of two ponics that were suffering from hyperlipaemia, to detine the influence of this treatment on the lipoprotein spectrum. 


\section{Materials and Methods}

\section{(A) The animals for the typing of hyperlipoproteinuemias}

To obtain data on clinically normal animals, according to the criteria o Schotman and Wagenaar [1], blood was collected from four Shetland ponies in foal. They all had been under the regular control of veterinary clinicians for a considerable period of time, and were normally fed. The patients were seven sick ponies which had beéh referred to the Clinic for Large Animal Medicine and were found to have lipaemic serum on first examination. Patient 1 had steatitis and a worm infection, pa ${ }^{2}$ ient 2 was emaciated probably as a result of strangles, patient 3 had colic, patient 4 was pregnant ard had nothing seriously wrong, patient 5 had had a lochiometra, patient 6 had a peritonitis traumatica, patient 7 showed a worm infection and patient 8 suffered from salmonellosis. All patients had a very poor appetite at the onset of the treatment. Also included was a pregnant Shetland pony which had induced hyperlipoproteinaemia as a result of 13 days of forced fasting. The animal was clinically normal at the onset of the fasting period and ir the 8 th month of gestation. With the exception of two animals all ponies died in spite of treatment.

\section{(B) The animals for the blood transfusions}

The two normal ponies, acceptors, were about 8 months pregnant. Both animals belonged to the Clinic for Large Aninal Medicine and were examined regularly by their veterinarians. Both ponies belonged to the above-mentioned group of normal poinies.

The hyperlipaemic ponies (donors). Donor 1 was a pony that was referred to the clinic as a fatient suffering from a worm infection, a severe acidosis and hyperlipoproteinaemia (type 2). Donor 2 was the above-mentioned pregnant Shetland pony, suffering from hypu-lipaemia (type 3) as a result of forced starvation for 13 days.

\section{Trarsfusion 1}

After adjusting the $\mathrm{pH}$ of the blood by hicarbonate infusion, 2.7 litres blood were collected using heparin as anticoagulant $(2 \mathrm{mig} / \mathrm{ml}$ blood $)$. Immediately after collection, this blood was transfused into acceptor 1 during a time interval of $30 \mathrm{~min}$. Blood samples were taken for analysis just before transfusion and $15 \mathrm{~min}, 30 \mathrm{~min}, 1,2,3,4,6$ and $12 \mathrm{~h}$ after the transfusion was completed.

\section{Transfusion 2}

Three litres of blood were collected using sodium citrate as anticoagulant (10 $\mathrm{mg} / \mathrm{ml}$ blood) and the blood was transfused into acceptor 2 during a timo interval of $24 \mathrm{~min}$. Blood samples were taken for analysis just before transfusion and $1,3,6,8,12,22.30,48$ and $72 \mathrm{~h}$ after the transfusion was completed. After the transfusions were completed both acceptor ponies ate normally.

The animals for the experiments during treatment (patients)

Patient I was a 6-month-old Shetland pony suffering from hyperlipopro- 
teinaemia only and presented as a patient at the Clinic for Large Animal Medicine. This patient was in a poor condition. Patient II was a 7-year-old Shetland pony suffering from hyperlipoproteinaemia. This pony seemed to be in a fairly good condition when presented to the Clinic. Colic was diagnosad. At acceptance both ponies refused to eat; both ponies subsequently recovered. The treatment with glucose, galactose and insulin was as described previously [11]. During the therapy water, hay and food concentrates were available.

\section{Preparation of blood serum}

An 8-10 ml sample of blood was collected in a $15 \mathrm{ml}$ centrifuge tube, left at room iemperature for $30-60 \mathrm{~min}$ and centrifuged at $3000 \times \mathrm{g}$ for $10 \mathrm{~min}$. When the serum was to be stored for a longer period, 1 drop of a $5 \%$ solution $(\mathrm{w} / \mathrm{v})$ of merthiolate was added and the serum stored at $4^{\circ}$.

\section{Fractionation of lipoproteins by preparative ultracentrifugation}

The fractionation of blood serum lipoproteins was achieved by a combination of ultracentrifugation* and precipitation [12]. The LDL fraction and the combined HDL and albumin bound free faity acid fraction were separated by means of heparin- $\mathrm{MnCl}_{2}$ precipitation according to Burnstein and Samaille [13]. The HDL and the albumin bound FFA were not separated. The lipids present in the various lipuprotein (LP) fractions were extracted with methanol-chloroform $(1: 2, \mathrm{v} / \mathrm{v})$, purified by partition according to Folch et al. $[14]$, and determined gravimetrically after evaporation of solvent.

\section{LP electrophoresis}

Paper electrophoresis was carried out exactly according to Lees and Hatch [15].

\section{Lipid aralysis}

Aralysis of the lipids was performed by quantitative th 7 -layer chromatography $[16]$.

The lupiu composition was messured by densitometry with the exception of the phospholipids which were estimated directly in the lipid extract by colorimetric determination of plicsphorus [17]. The rnethods of estimation of the other blood constituents mentioned in this article were as previously described [4].

For convenience many dala ir the tables sre rounded wif.

\section{Results}

From Table I, last column, it appears that in healthy ponies the distribution of the toial lipoprotin lipids over the four commonly recognize 4 LP fractions shows a remar:ably constant paitern**; about two-thirds of all serum lipids are present as $\mathrm{HOL}$ and the remainder is almost equally divided between VLDL and LDL.

* Swing, out rotor, $3 \times 5 \mathrm{mi}$, No. 2414 : M.S.E. $\$ 550$ centrifuge.

*: Chylo, range $1-3$ is eight so; LDI, range $16-18$ weight $\%$; VLDL, range $10-19$ weight $\%$; HDL, range $62-72$ weigh: 


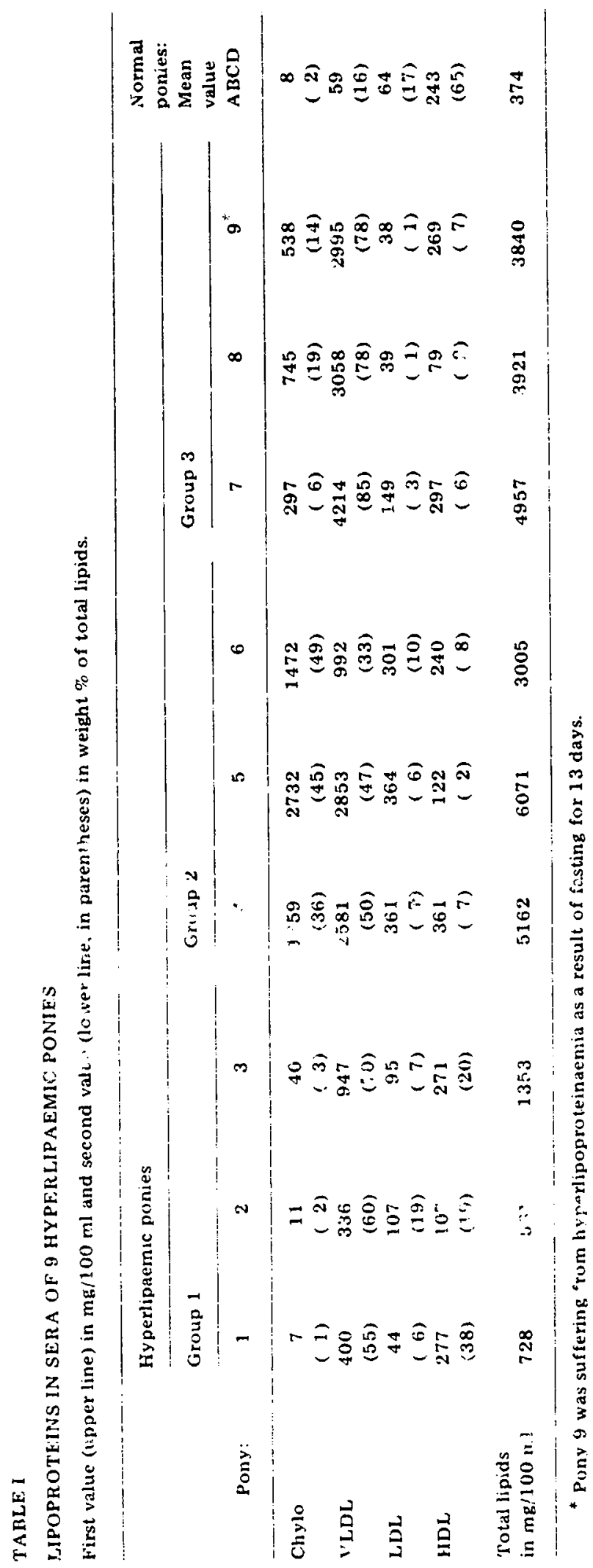




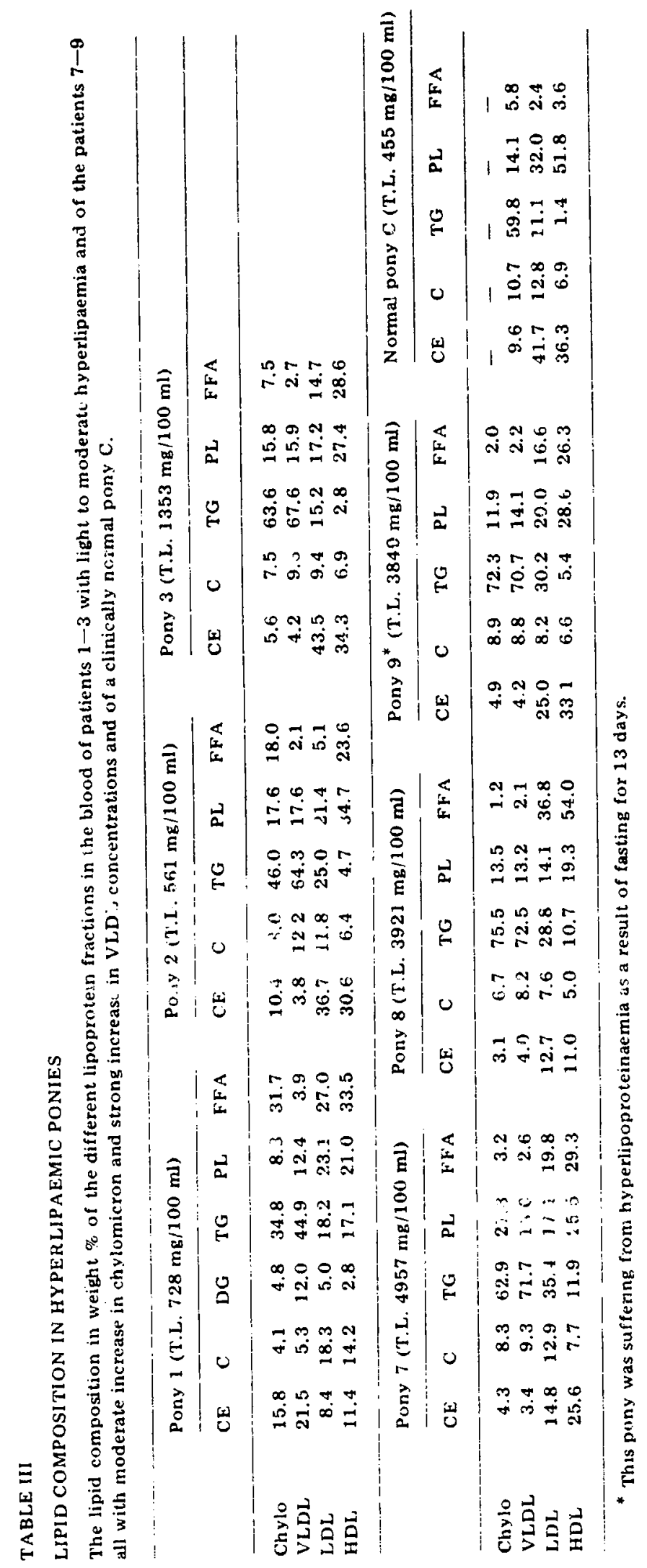


As can be seen from Table II, last column, the distribution of the total lipids over the main lipid classes shows a fairly constal.. picture in healthy animals; phospholipids (PL) and TG logether make up 54\% of the total serum lipid content.

The composition of the lipids in the LP fractions of the normal pony $\mathrm{C}$ is given in Table III.

We find FFA in all fractions, indicating that they are not all albumin bound (and would be concentrated only in the HDL fraction, see Methods).

\section{(A) Hyperlipaemic ponies (the patients)}

In Table I are summarised the LP-distributions in the serum of patients which had lipaemic serum at first examination. Total lipoproteins (lipids) are oniy slightly elevated in patients 1 and 2 , moderately in 3 and strikingly so in ponies 4-9. Most prcnounced is the increase in chylomicrons, hardly present in thi normal state and increasing to $c$ ver $45 \%$ of the total lipids in severe hyperlipaemia (patients 5 and 6 ). The absolute values are clearly elevated in patients 4-6. Only in patients $1-3$, are the concentrations of chylomicrons within acceptable limits.

In all of the hyperlipaenic sera, the VLDL concentrations are mc:e than 5 times as high as the values in the reference sera; in the more severe cases (patient 7), VLDI concentration increases up to 70 times. In only three cases (patients 4-6), is the concentration of LDL mcderately increasea.

The HDL concentration is not increased at all, but in patients 2,5 and 8 , a clear decrease is found. If we compare LP distributions, we observe a fall in HDL from $65 \%$ (mean normal value) to 27 in patients 5 and 8 .

The distribution and concentrations $c i$ the different lipids are summarized in Table II. All lipid classes are elevateo, but TG is most strongly affected, a 50 -fold increase from $40 \mathrm{mg} / 100 \mathrm{ml}$ to $2000 \mathrm{mg} / 100 \mathrm{ml}$ being quite common. The increase in CE (from about $128 \mathrm{mg} / 100 \mathrm{ml}$ to, at the most, $413 \mathrm{mg} / 100$ $\mathrm{ml}$ ) is far less than the increase in $\mathrm{C}$ from $22 \mathrm{mg} / 100 \mathrm{ml} \mathrm{to}$, at the most, 516 $\mathrm{mg} / 100 \mathrm{ml}$. In patient 8 especially the $\mathrm{CE}$ concentration is extremely low. From the iriglyceride, cholesterylester and chclesterol values some rations (viz. $\mathrm{C} / \mathrm{CE}$ and $\mathrm{TG} /$ total $\mathrm{C}$ ) are calculated, in order to search for some characteristics in the lipid distributions.

From our former results in therapy, we have the impression that one might distinguish different types of hyperlipoproteinaemia in ponics. Therefore, in Tables I and II our patients are divided into three grou: - in crder to sse whether any specific differences are evident.

In group 1 (patients $3-3$ ), with slightly to moderately elevated TL levels, over $55 \%$ of the TL is fomd in the VLDL fraction, the absolute levels being moderately elevated. Chylomicron levels are hardly elevated.

In group 2 (patierts 4-6), either the chylomicrons and the VLDL fractions are very highly levated in a relative as well as in an abs-lute sense; the LDL fractions are moderately elevated.

Ir: group 3 (patients 7-9), the VLDL fraction comprises over $78 \%$ of the total lipids; the chylomicron fraction being modorately elevated in terms of weight $\%$ of total ipirs.

Furthermore, in Table III the lipid compositions of the fractions of hyper- 
lipaemic sera are compared with those of normal serum (pony $C$ ). As aiready mentioned FFA would be expected to be specifically present in the HDL fraction as a result of the method of fractionation, but FFA are found in all fractions. The percentage of PL is low in the LDL and HDL fractions of the serum of the patients $1-3$.

Noticeable also is the rather high percentage of $\mathrm{CE}$ in the chylomicron fractions in ponies 1 ard 2 . The same phenomenon has been reported for chylomicrons in fasting human sera [12].

In the serum of patients 7-9 we found that all the chylomicrons and VLDL fractions have a high percentage of TG as usual, although the LDL fractions $(3,1$ and $1 \%$ by weight of the total serum lipids) also have an elevated percentage of $\mathrm{T} G$. The phospholipid content of the HDL is decreased.

Electrophoreiic separation of lipoproteins. Very clear lipoprotein patterns were obtained by means of paper electro horesis. The electrophoretic patterns wcre in excellent agreement with the above-mentioned figures of ultracentrifugal analysis. Chylomicrons are conceritrated in bands very well separated from pre- $\beta$-LP.

\section{(B) Transfusions}

Transfusion 1. In Table IV, the lipoprotein values after transfusion are presented. Shortly (15 $\mathrm{min})$ after completing the transfusion, we observed a strong rise in the VLDL fraction, a strong rise in the HDL fraction (expected because of the increase in albumin bound FFA in this fraction due to the fractionation procedure), and hardly any change in the chylomicron concentration.

Up to $12 \mathrm{~h}$ (the maximum time interval during this study) we find a steady and very strong increase in this chylomicron concentration and after a strong drop between 15 and $30 \mathrm{~min}$ a stcady increase in the VLDL concentration, the HDL fraction returning to normal values. In the time interval of $0-6$ $h$, a definite increase : $:$. $n$ ! concentration can be observed. In Table $V$ the

\section{TABLE IV}

LIPOPROTEIN COMPOSITION IN SERUM OF PONY A AFTER TRANSFUSION OF 2.7 LITRES OF BLOOD FROM PONY 1 (ACIDOSIS AND HYPERLIPOPROTEINAEMIA)

First value (upper line) in $\mathrm{mg} / 100 \mathrm{ml}$ and second value (lower line, in parentheses) in weight \% of total lipids.

\begin{tabular}{|c|c|c|c|c|c|c|c|c|c|c|}
\hline $\begin{array}{l}\text { Time } \\
\text { after } \\
\text { trans- } \\
\text { fusion }\end{array}$ & $\begin{array}{l}\text { Donor } \\
1\end{array}$ & $\begin{array}{l}\text { Ar- } \\
\text { cep- } \\
\text { tor } 1\end{array}$ & $15 \mathrm{~min}$ & $3: \mathrm{min}$ & $1 \mathrm{~h}$ & $2 h$ & $3:$ & $\therefore \quad 3$ & $6 \mathrm{~h}$ & $12 \mathrm{~h}$ \\
\hline Chylo & $\begin{array}{c}272 F \\
(45)\end{array}$ & $\begin{array}{l}6 \\
(2)\end{array}$ & $\begin{array}{c}18 \\
(1)\end{array}$ & $\begin{array}{l}268 \\
(20)\end{array}$ & $\begin{array}{l}179 \\
(14)\end{array}$ & $\begin{array}{l}228 \\
(18)\end{array}$ & $\begin{array}{l}581 \\
(45)\end{array}$ & $\begin{array}{l}366 \\
(32)\end{array}$ & $\begin{array}{l}580 \\
(47)\end{array}$ & $\begin{array}{l}851 \\
(53)\end{array}$ \\
\hline VLDL & $\begin{array}{r}2868 \\
(47)\end{array}$ & $\begin{array}{c}57 \\
(19)\end{array}$ & $\begin{array}{l}624 \\
(42)\end{array}$ & $\begin{array}{l}176 \\
(13)\end{array}$ & $\begin{array}{l}19 c \\
\text { (14) }\end{array}$ & $\begin{array}{l}127 \\
(10)\end{array}$ & $\begin{array}{l}364 \\
(28)\end{array}$ & $\begin{array}{l}196 \\
(17)\end{array}$ & $\begin{array}{l}270 \\
(22)\end{array}$ & $\begin{array}{l}444 \\
(28)\end{array}$ \\
\hline LDL & $\begin{array}{l}381 \\
(6)\end{array}$ & $\begin{array}{c}48 \\
(16)\end{array}$ & $\begin{array}{l}188 \\
(13)\end{array}$ & $\begin{array}{l}540 \\
(40)\end{array}$ & $\begin{array}{l}551 \\
(43)\end{array}$ & $\begin{array}{l}408 \\
(33)\end{array}$ & $\begin{array}{l}146 \\
(11)\end{array}$ & $\begin{array}{l}331 \\
(28)\end{array}$ & $\begin{array}{l}173 \\
(14)\end{array}$ & $\begin{array}{l}108 \\
(7)\end{array}$ \\
\hline HD̄ & $\begin{array}{c}97 \\
(2)\end{array}$ & $\begin{array}{l}188 \\
(63)\end{array}$ & $\begin{array}{l}661 \\
(44)\end{array}$ & $\begin{array}{l}365 \\
(27)\end{array}$ & $\begin{array}{l}374 \\
(29)\end{array}$ & $\begin{array}{l}481 \\
(\because 9)\end{array}$ & $\begin{array}{l}207 \\
(16)\end{array}$ & $\begin{array}{l}273 \\
(23)\end{array}$ & $\begin{array}{l}211 \\
\text { (1) }\end{array}$ & $\begin{array}{l}189 \\
(12,)\end{array}$ \\
\hline TL & 6071 & 299 & 1491 & 1349 & 1296 & 1244 & $! 298$ & 1166 & 1234 & 1592 \\
\hline
\end{tabular}


TABLE V

LIPIDS IN SERUM OF ACCEPTOR 1 AFTER TRANSFUSION OF 2.7 LITRES OF BLOOD FROM DONOR 1 (ACIDOSIS AND HYPERLIPOPROTEINAEMIA)

First value (upper line) in $\mathrm{me} / 100 \mathrm{ml}$ ans second value (lower line, in parentheses) in wight \% of total lipids.

\begin{tabular}{|c|c|c|c|c|c|c|c|c|c|}
\hline $\begin{array}{l}\text { Time after } \\
\text { transfusion }\end{array}$ & $\mathbf{0}$ & $15 \mathrm{~min}$ & $30 \mathrm{~min}$ & $1 \mathrm{~h}$ & $2 \mathrm{~h}$ & $3 \mathrm{~h}$ & $4 \mathrm{~h}$ & $6 \mathrm{~h}$ & $12 \mathrm{~h}$ \\
\hline$C E$ & $\begin{array}{l}125 \\
(42)\end{array}$ & $\begin{array}{l}194 \\
(13)\end{array}$ & $\begin{array}{l}216 \\
(16)\end{array}$ & $\begin{array}{l}207 \\
(16)\end{array}$ & $\begin{array}{l}199 \\
(16)\end{array}$ & $\begin{array}{l}208 \\
(16)\end{array}$ & $\begin{array}{l}233 \\
(20)\end{array}$ & $\begin{array}{l}222 \\
(18)\end{array}$ & $\begin{array}{l}223 \\
(14)\end{array}$ \\
\hline TG & $\begin{array}{c}57 \\
(19)\end{array}$ & $\begin{array}{l}447 \\
(30)\end{array}$ & $\begin{array}{l}351 \\
(26)\end{array}$ & $\begin{array}{l}324 \\
(25)\end{array}$ & $\begin{array}{l}199 \\
(16)\end{array}$ & $\begin{array}{l}662 \\
(51)\end{array}$ & $\begin{array}{l}373 \\
(32)\end{array}$ & $\begin{array}{l}617 \\
(50)\end{array}$ & $\begin{array}{l}923 \\
(58)\end{array}$ \\
\hline C & $\begin{array}{l}24 \\
(8)\end{array}$ & $\begin{array}{l}164 \\
(11)\end{array}$ & $\begin{array}{l}148 \\
(11)\end{array}$ & $\begin{array}{l}155 \\
(12)\end{array}$ & $\begin{array}{l}137 \\
(11)\end{array}$ & $\begin{array}{l}104 \\
(8)\end{array}$ & $\begin{array}{l}128 \\
(11)\end{array}$ & $\begin{array}{l}136 \\
(11)\end{array}$ & $\begin{array}{l}143 \\
(9)\end{array}$ \\
\hline FFA & $\begin{array}{c}21 \\
(7)\end{array}$ & $\begin{array}{l}507 \\
(34)\end{array}$ & $\begin{array}{l}445 \\
(33)\end{array}$ & $\begin{array}{l}453 \\
(35)\end{array}$ & $\begin{array}{l}547 \\
(44)\end{array}$ & $\begin{array}{l}78 \\
(6)\end{array}$ & $\begin{array}{l}257 \\
(22)\end{array}$ & $\begin{array}{c}86 \\
(7)\end{array}$ & $\begin{array}{l}64 \\
(\quad 4)\end{array}$ \\
\hline PL & $\begin{array}{c}72 \\
(24)\end{array}$ & $\begin{array}{l}179 \\
(12)\end{array}$ & $\begin{array}{l}189 \\
(14)\end{array}$ & $\begin{array}{l}156 \\
(12)\end{array}$ & $\begin{array}{l}162 \\
(13)\end{array}$ & $\begin{array}{l}246 \\
\text { (19) }\end{array}$ & $\begin{array}{l}175 \\
(15)\end{array}$ & $\begin{array}{l}173 \\
(14)\end{array}$ & $\begin{array}{l}239 \\
(15)\end{array}$ \\
\hline Total lipids & 299 & 1491 & 1349 & 1296 & 1244 & 1298 & 1166 & 1234 & 1592 \\
\hline
\end{tabular}

corresponding lipid values and some lipid ratios are summarized.

If we compare the values for 0 and $15 \mathrm{~min}$, we see a strong increase in triglyceride (TG) and FFA concentration. It is striking that the FFA concentration decreases just at the moment that the TG and the VLDL concentration, but especially the chylomicror concentration, increase. The alterations in the FFA and TG concentration parallel, in general, the lipoprotein concentration, e.g., the dip in chylomicron concentration at $4 \mathrm{~h}$ is reflected by a dip in TG concentration.

Transfusion 2. A totally different response is measured (Table VI). It is surprising that no greater response takes place in the time interval up to $12 \mathrm{~h}$ after transfusion. After an initial increase measured frc $\mathrm{a}$ around $1 \mathrm{~h}$ up to $8 \mathrm{~h}$ âtter transfusion hardly any change could be noted. Then an almost explosive

T:BLEVI

LIPOPROTEIN COMFOSITION IN GERUM OF PONY B AFTER TRANSFUSION OF 3 LITRES OF BLOOD FROM PONY 2 (HYPERLIPARMIA INDUCED BY FASTING)

first value (upper line) in $\mathrm{mg} / 100 \mathrm{~m}$ ! and second value (lower line, in $\cdot 25$ atheses) in weight \% of total lipids.

\begin{tabular}{|c|c|c|c|c|c|c|c|c|c|c|c|}
\hline $\begin{array}{l}\text { Tiziz after } \\
\text { transfusion }\end{array}$ & Donor 2 & $\begin{array}{l}\text { Aciep- } \\
\text { tor } 2\end{array}$ & in & $3 \mathrm{~h}$ & in & $\times h$ & $12 \mathrm{~h}$ & $23 \mathrm{~h}$ & $30 \mathrm{i}$ & $20:$ & $\cdot$ מ. \\
\hline$\cdots$ & $\cdot \cdot$ & $\cdots \cdots$ & $\cdots$ & & & & & $\cdots-$ & & 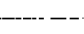 & $\ldots$ \\
\hline \multirow[t]{2}{*}{ Chylo } & 504 & 4 & 13 & 3 & 4 & 3 & 12 & 39 & 373 & 7 & 2 \\
\hline & $(14)$ & $(1)$ & $(1)$ & (1) & (1) & ( 1 ) & ( 2$)$ & $(3)$ & $(13)$ & (2) & (1) \\
\hline \multirow[t]{2}{*}{ VIDI. } & 2880 & A6 & 194 & 34 & 47 & 51 & 176 & 719 & 2237 & 56 & 50 \\
\hline & (78) & (:0) & (19) & (7) & $(10)$ & $(10)$ & $(27)$ & $(59)$ & $(80)$ & $(12)$ & (11) \\
\hline \multirow[t]{2}{*}{ LDL } & $4 x$ & 89 & 224 & 111 & 107 & 118 & 108 & $11 !$ & 27 & 105 & 100 \\
\hline & (1) & $(15)$ & $(22)$ & (23) & $(22)$ & $(22)$ & (16) & $(9)$ & $(1)$ & (23) & (21) \\
\hline \multirow[t]{2}{*}{ EDL } & 249 & 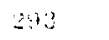 & 592 & .327 & 317 & 356 & 359 & 356 & 155 & 285 & 308 \\
\hline & $(7)$ & $(23)$ & $(58)$ & $(69)$ & $(67)$ & $(67)$ & $(55)$ & $(29)$ & $(6)$ & $(63)$ & (67) \\
\hline $\mathrm{TL}$ & 3681 & $\$ 06$ & 1023 & 475 & $.17 \mathrm{~J}$ & 528 & 655 & 1225 & 2782 & 453 & 460 \\
\hline
\end{tabular}


increase in VLDL concentration with a maximum at $30 \mathrm{~h}$ after transiusion followed. This increase was accompanied by a dip in the HDi, co:ventration. Besides that there was a definite but relatively moderate increase in chylomicrons. After $48 \mathrm{~h}$ the pattern was similar to that before the transfusion.

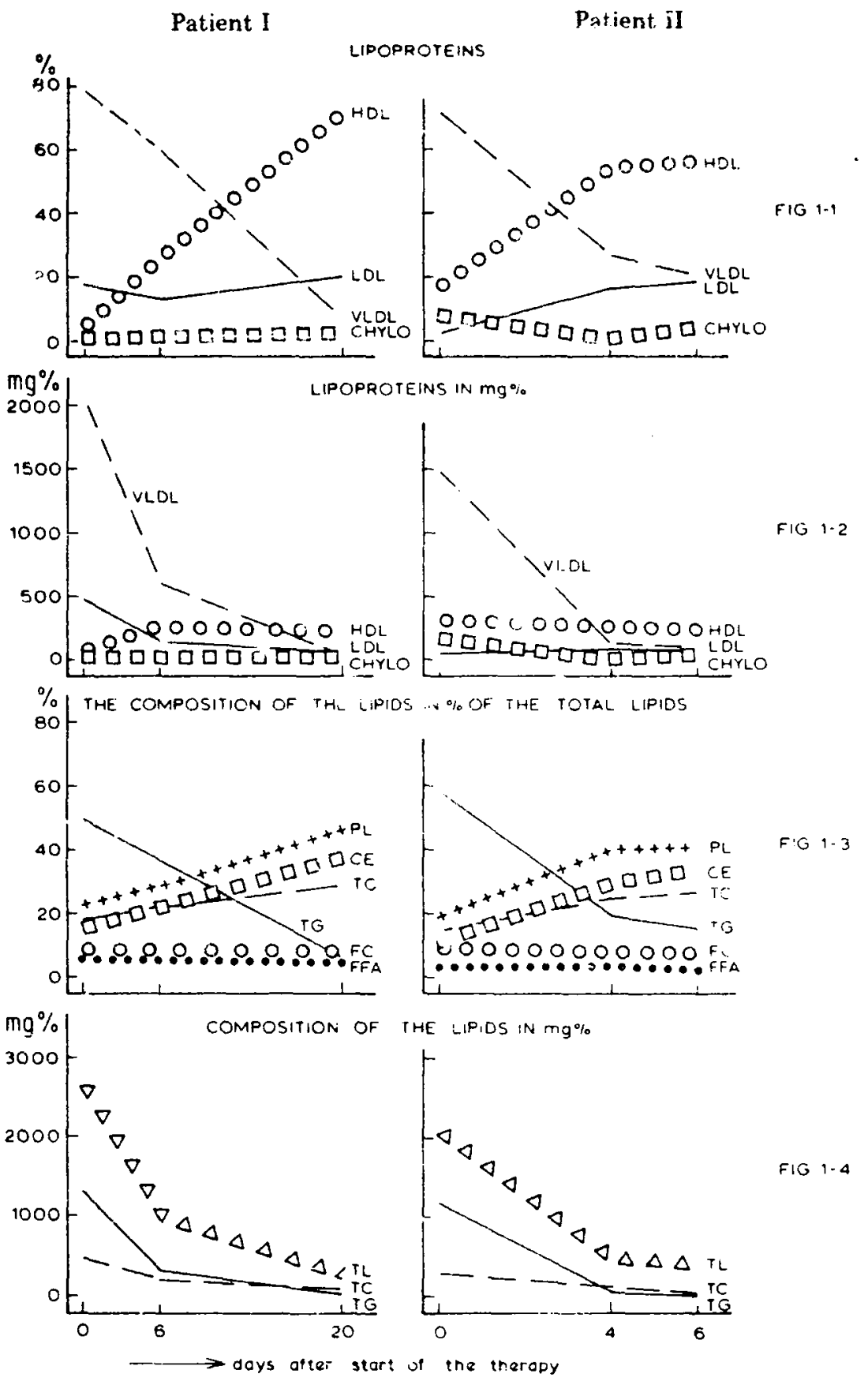

Fig. 1. The changes in the lipoprotein spectrum and in the lipid composition in perceitiages and in $\mathrm{mg} / 100$ $\mathrm{ml}$ in the blcod of the patients $I$ and II during treatment with glucose, galactose and insulir. 
(C) The influence of treatment

The changes in lipids and lipoproteins in the blood of hyperlipaemic ponies during treatment with glucose, galactose and insulin are shown in Fig. 1. In both patients the same deviations in the lipoprotein patterns were observed, namely a slight increase of the chylomicron concentration and a clear increase only in VLDL concentration. Durirg treatment there was a rapid decrease in VLDL and TG concentrations, but also in the glycerol and the activities of the different enzymes (AP, LDH and SDH).

\section{Discussion}

\section{(A) The different types of hyperlipoproteinaemia}

Upon consideration of the results in Table I, it is apparent that the first change in the lipoprotein pattern during the development of hyperlipoproteinaemia in ponies (patients $1-3$ ) seems to be an increase in the VLDL concentration accompanied by a moderate rise in the TI and TG values (type 1 ). This change is much more pronounced in patients 7 and 8 and in patient 9 with induced hyperipoproteinaemia (type 3 ); the chylomicron fraction is also some. what elevated.

The lipoprotein concentrations in patients 4-6 (type 2) are changed in a iypical way, as chylomicrons and VLDI, are present in nearly equal very large amounts; the LDL concentration is also clearly elevated. It is possible that hyperlipoproteinaemia in ponies evolves ironı a pattern such as that in conies of group 1 through the pattern of group 3 leading to the pattern of group 2 . This seems unlikely, however, because of the specific increase in LDL concentration in type 2 .

As a result of this study we may state that, in ponies, three types of hyperlipoproteinaemia may be distinguished. These are: (Type 1) a type with a predominantly strong increase in VLDL and a zero to moderate increase in chylomicron concentration. (Trederickson type IV it human hyperipoproteinaemia); (Type 2) a type in which nearly equal but highly elevated concentrations of chylomicrons and VLDI. can be found (f'rederickson type $V$ in human hyparlipoproteinaemia) in association with a certain but less pronounced rise in L. DL concentration; (Tyne 3) a type which is induced by fasting. This last type is isut yet clearly established.

Clear information can be obtained by the use of paper electroph:urcis according to Lees and Hatch [15] by which the tw. assumed types can be distinguished on the bases of an increase in VLDL, only or a ............ iease in VLDL, and chylomierons.

\section{(8) The transfusions}

Conparing the changes in lipoprotein concentrations after the transfusions of lipaemic blood into healthy ponies ('Tables $1 \mathrm{~V}-\mathrm{VI}$ ) we observe different reactions in the blood of heal hy ponies. In both experiments there is at first an increased or increasing HDL concentration, followed by a decrease in that concertration. This decrease is accompanied by a rise in the VLDL and chylomicron conceniration. In the case of tianufiusion 1 (donor 1 - acceptor 1 ) the increase in total lipids in blood from acceptor $\mathrm{A}$ is more or less as can be 
expected from mixing the sera; this total lipid value does not change very much up to at least $12 \mathrm{~h}$.

The VLDL level still increases up to at least $12 \mathrm{~h}$ (maximal time of this experiment), accompanied by an increase in TG concentration, but a decrease in FFA concentration. The chylomicron level is unexpectedly low directly after the completion of the trar. fusion, but steadily increases at a high rate up to at least $12 \mathrm{~h}$. The initial low values can be explained by a high turnover rate of chylomicrons as evidenced by the high FFA levei (Table V).

The immediate increase in the HDL fraction (HDL + FFA) can partially be explained by taking into account the fact that there is a quick FFA release from the administered lipoproteins. This release of FFA is acceierated because the administered heparin has an activating effect on the lipoprotein lipase in the blood of the recipient pony $[5]$. The data concerning the course of the FFA and TG levels in Table $\mathrm{V}$ incieate that the greater part of this amount of FFA probably is taken up into triglycerides and finally causes a strong increase in the chylomicron and an increase in the VIDL fraction (Table IV).

The supposition that the initial increase in the HDL fraction originates from a clear increase in FFA is supported by the similarly observed decrease in the HDL fraction after $2 \mathrm{~h}$. This is exactly the time that the FFA concentration is decreasing and the triglyceride concentration and the VLDL and chylomicron fractions are increasing (Tables IV and V). The response of acceptor $\tilde{z}$, which received blood with a strongly increased VLDL level and a moderately increased chylomicron level was different. Up to $12 \mathrm{~h}$ after the transfusion nothing happened. However between 22 and $30 \mathrm{~h}$ there was a clear decrease in the HDL concentration and an explosive rise and fall from and to the normal values of VLDi. The chylomicron level increases moderately at the same time. Probably the administered lipoproteins cannot be hyclrolysed at the same rate because in this case ine lipoprotein linase is not activated by heparin. Therefore, the different sesponse could be expected. From the chylomicron and VLDL levels $12 \mathrm{~h}$ - f that a greater availability of FFA can lead to an increased production of chylomicrons and VLDL. The fact that the HDL fractions after the transfusionis are increased until the VLDL and chylomicron fractions begin to rise suggests that the fatty acids that are released from the administered lipoproteins are gathered in the HDL fraction, probably bound to albumin. After some time these FA are used for the synthesis of TG. These TG are taken up in the chylomicrons and VLDL. The character of the risires seems to depend on the rate at which the fatty acids are released. The higiter this rate of release, the more chylomicrons are synthesized. When the release of fatty acid; is more gradual, then the extra offered lipids can be workec $u_{p}$, by synthesizing more VLDL.

It is not clear to what extent observed differences between the two transfusions are influenced by the type of hyperlipoproteinaemia that occurs in the donor of the lipaemic blood.

(C) The changes occurring during treatment

In the prolonged treatment with glucuse, galactose and insulin, both the patients treated appear to have suffcred from liver damage, as the LDII and AP 
concentrations were increased [18]. The high blood glycerol concentration that we measured in the blooc of the two patients treated suggests that the hyperlipoproteinaemia occurring in these patients is the result of increased fat mobilization. The increased concentration of VLDL suggests that the same type of hyperlipoproteinaemia (type 1) was present in botr. patients (Fig. 1). From the changes in the glycerol concentration (Fig. 1) it is evident that the therapy leads to a decrease in fat mobilization and that the initially high TG concentration generally decreased. The infuence of the therapy on the deviations in the lipoprotein spectrum is also very obvious. A decrease in the percentage of VLDL and a rise in the percentage of HDL can be observed in both jatients (Fig. 1). After the mobilization decreases as a result of therapy, the remuval of the lipids (riainis TG) from the liver to the different tissues and the adipocytes can apparently be effected by gradually returning to the synthesis of the normal pattern of lipoproteins (Fig. 1). The observation that the PL concentration as well as the percentage of HDL increase supports this hypothesis.

The observation that a therapy with glucose alone did not result in a decrease of the $\mathrm{TL}$ concentration in the blood $[3,5]$ suggests that insulin plays an important role. One of the activities of insulin is to stimulate FFA uptake in the adipocytes [19-21]. Therefore, the eyplanation for the observed changes might rather be sought in a decreased fat mobilisation [22] and an iricreased FFA uptake in the adipocyte. Ferhaps a ruily normally functioning liver can still regulate the lipid transport during an extra increase in TG without a snift in lipoprotein synthesis. A liver with a large pool of endogenous triglycerides, for instance, cannot manage that $[22]$. Which comes ïirst, an increased concentration of TG in the liver or the shift in lipoprotein synthesis, is not known at this time.

Summarizing, it can be staied that increased fat inubiiization in ponies with slight liver damage results in a shift in lipoprotein synthesis. The greater amount of fat mobilized, the mure VLDL and chylo..icrons are synthesized.

Treatment of ponies suffeving from hyperlipoproteinaemia with giucose, galactose and insulin can effect a decrease in tota! lipid concentration and a correction of the disturbed $\mathrm{L} . \mathrm{P}$ pattern in the blood.

\section{Acknowledgements}

We are grateful to Miss $\mathrm{T}$. Boonders and $\mathrm{Mr} \mathrm{H}$. "an der Voort for their skilled assistance.

This study was supporied by a grant from Z.W.O., The Netherlands.

\section{References}

1 A.J.H. Schntman and G. Wagenaar, Zentralol. Vet. Med., A 16 (1969) $1-7$

2 L. Ericksen and M. Simesen, Nord. Vet. Med., 22 (1970) $273-284$

3 A.J.H. Schotr tis and J. Kroneman, Tijdschr. Diergeneesk., 93 (1968) 774-779

4 Ti. Wensins. A.H. Schotman and J. Kroneman, Neth, J Vet. Sci., 98 (1973) 673-680 (Quart. English Issut:

5 A.J.H. Schotman. Thesis, Utrecht, 1965

6 A.L. Baet: and J.E. Pearson, Am. J. Vet. Res., 33 (1972) 1941-1946 
7 Bartley, I.C., Equine lipenia, in J.J. :-sneko and C.E. Cornolius (eds), Clininal Binchemistry of Domestic Animals, Academic Press, $\mathrm{x}$ ijw York, 1970. 88-92

8 D.S. Frederickson and R.S. Lees, Cirmu!ation, 31 (1965) 321--327

9 M.D. Morris, D.B. Zilversmit and H.F. :Hirtz, J. Lipid Res., 13 (1972) 38.3-389

10 J.C. LaRosa, A.I. Levy, H.G. Windmueler and D.S. Fredericksor, J. Lipid Rcs., 13 (1972) 3jô-36?

11 Th. Wensing, A.J.H. Schotman and J. Kroneman, Netu, J. Vet. Sci., 5 (1973) 145-147

12 C.M. van Gent, Prot. Biol. Fluids: (1972) p. 75

12 M. Buistein and J. Samaille, Clin. Chir.1. Acta, 5 (1960) 609

14 J. Folch. M. Lees zıd G.H. Sloane-Stanley, J. Biol. Chem., 226 (1957) 497-505

15 R.S. Lees and E.T. Hatch, J. Lab. Clin. Med., 61 (1963) 518-528

16 C.M. van Gent. Z. A nal. Chem., 236 (1968) 344-350

17 C.J.F. Eöttcher, C.M. van C ?nt and C. Preis, Anal. Clin. Acta, 24 (1961) 203--204.

18 J.J. Kanek, and C.E. Correlius, Clinical Bichemistry of Domectic Animals Vul. I. Acarjemic Press New York, 1970, p. 210

19 R.W. Buicher, J.G.T. Sneyd, C.R. Pa:k and E.W. Sutherland, Jr., J. Biol. Chem., 241 (1966) 1651-1653

20 G.F. Cahill, In K. Rodahland B. Issekutz (eds), Fat as Tissue, McGraw-Hii!l, New York, 1964, p. 169

21 J.N. Fain, V.P. Kovacev and R.O. Scow, r drocrinology, 78 (1966) 773-775

22 E.L. Bierman, Isx. J. Med. Sci., 8 (1972) 303-308

23 P.L. Nestel, J. Clin. Inv., 43 (1964) 943-949 